\title{
Citizenship for Those who Invest into the Future of the State is Not Wrong, the Price Is the Problem
}

\author{
Magni-Berton Raul
}

\begin{abstract}
Roughly two thousand years ago, Roman citizenship began to be sold to rich foreigners. As a consequence, rather than a way to share equal duties and rights, citizenship by the third century C.E. had become an aristocratic title. It divided people instead of rallying them. It increased inequalities instead of reducing them.
\end{abstract}

The current situation is somewhat similar. Rich people have access to rich countries' membership, and poor people remain on the wrong side. Thus, I sympathise with Shachar's concerns and I think we should avoid to reproduce what we have already experimented in our ancient history.

However, I do not agree with the way in which both Shachar and Spiro have identified the problem. Consider, for example, a situation in which a foreigner asks for access to citizenship in those terms: 'I want to share the responsibility of my failures and achievements with you, and I'd like to invest in you and to be partly responsible of your achievements and your failures.' This is a touching statement of solidarity and identification with a group. I have called it the stockholder principle: individual citizens are like a joint-stock company in which fellow-citizens invest. The consequence of these collective investments is a shared responsibility for individuals' achievements. Moreover, the right to benefit from public support is associated with the duty to invest in other fellow-citizens' life projects. These duties are embodied in specific taxes for public investment. Thus, each citizen is also a stockholder with respect to other citizens.

Thus I would not say that the Maltese Parliament voted to 'sell' the Maltese passport when it granted citizenship for $€ 650,000$. From a foreign investor's point of view, given that she makes the above statement and is ready to invest in the future of Maltese citizens, she acquires a moral claim to become citizen. She does not only give a sum of money in exchange for rights; she also becomes more largely committed to the duties of a Maltese 
citizen. In other words, she gains access to the Maltese nationality with an investment, which is a way to link her destiny to that of other Maltese.

So what is wrong with this beautiful story? Why are the Maltese people sceptical and why is international opinion critical? Of course, we could agree that the argument of externalities, mentioned by Shachar, is relevant: European citizens should also benefit from those new investments. Thus, the problem is identifying who decides the allocation of those investments: the government of Malta or the EU. Although these externalities are expected to be low, as Spiro points out, it can be argued that Maltese citizens free-ride because they alone benefit from the foreigners' will to become European, and this could be morally disputable.

Beyond that, the main argument I would like to develop here is that $€$ 650,000 seems, at first sight, a lot. Not in absolute terms, of course. Suppose, for example, a society in which people spend $€ 200$ on watching a film. Several others things are likely to be true in such a society. Firstly, there are some people that can afford to pay this price. Secondly, there are no other less expensive goods which are substitutable, such as for example theatre, sport or other entertainment. Perhaps this is because technological progress has improved cinema so that it delivers a specific pleasure one cannot find elsewhere. Alternatively, this may happen because theatres or circuses have simply gone bankrupt.

Analogically, in the case of naturalisation, several other things are likely to be true in virtue of the fact that people prefer to pay a considerable amount of money, rather than to proceed with alternatives. For example, in a society where people are ready to pay $€ 650,000$ for a passport, many of these alternatives are likely to be extremely burdensome, impractical, or unfair.

Let me assume that, until now, the Maltese way to naturalise foreigners has been fair according to the stockholder principle. In other words, a 'poor foreigner' can be naturalised, if she is ready to share the responsibility for her failures and achievements with Maltese citizens, as well as to invest in them and become partly responsible for their achievements and failures. Under this assumption, investing money in Malta, whatever the amount, is one fair way, among others, to gain access to citizenship. There is no reason, after all, to distinguish between financial and human investments.

But, if the Maltese law was fair, people would not be likely to invest $€$ 650,000 to be naturalised. Of course, they could love Malta. They also could be so wealthy that they prefer to pay this amount rather than spend time in human investments. More probably, however, the fact that people are ready 
to pay this amount reveals that the law is in fact too restrictive and does not provide other reasonable ways to become citizen.

Naturalisation in Malta is possible after five years of residence, but it includes discretionary conditions, the severity of which can vary across time. In other European countries specific conditions and varying periods of residence are required. The greater the severity, the greater the price for passports. Investor citizenship programmes should be used to create a fruitful community, not to maximise price.

To conclude, I do not believe that investor citizenship programmes in themselves are unfair. On the contrary, they can reveal, via a financial argument, how hard the naturalisation process is. All European countries are concerned with this issue: too restrictive laws prevent motivated people to give their contribution to the host country and they divide humanity into rich and poor, rather than into different united groups. Exactly as the Roman Empire did.

Open Access This chapter is licensed under the terms of the Creative Commons Attribution 4.0 International License (http://creativecommons.org/licenses/by/4.0/), which permits use, sharing, adaptation, distribution and reproduction in any medium or format, as long as you give appropriate credit to the original author(s) and the source, provide a link to the Creative Commons license and indicate if changes were made.

The images or other third party material in this chapter are included in the chapter's Creative Commons license, unless indicated otherwise in a credit line to the material. If material is not included in the chapter's Creative Commons license and your intended use is not permitted by statutory regulation or exceeds the permitted use, you will need to obtain permission directly from the copyright holder.

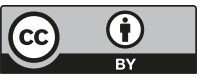

